\title{
A Survival Analysis on Fuel Cell Technology Patent Maintenance and Values Exploration between 1976 and 2001
}

\author{
Seng-Su Tsang, ${ }^{1}$ Feng-Chen Chang, ${ }^{1}$ and Wen-Cheng Wang ${ }^{1,2}$ \\ ${ }^{1}$ Department of Business Administration, National Taiwan University of Science and Technology, No. 43, Sec. 4, Keelung Road, \\ Da'an District, Taipei City 106, Taiwan \\ ${ }^{2}$ Department of Business Administration, Hwa Hsia University of Technology, No. 111 Gongzhuan Road, Zhonghe District, \\ New Taipei City 235, Taiwan \\ Correspondence should be addressed to Wen-Cheng Wang; wcwang@cc.hwh.edu.tw
}

Received 17 November 2014; Revised 10 February 2015; Accepted 3 March 2015

Academic Editor: Jaehwan Kim

Copyright (C) 2015 Seng-Su Tsang et al. This is an open access article distributed under the Creative Commons Attribution License, which permits unrestricted use, distribution, and reproduction in any medium, provided the original work is properly cited.

Fuel cell R\&D activities desirably arrive in patents; the costly maintenance fee challenges managers as well as researchers to whether or not renew existing patents. The key is, will the fuel cell patent's value be worth renewing? Thus assessment of patent value is essential. Our study focus online searching was made available after 1976, as the initial year to conduct the patent search. Up to 2001, there are 2269 patents classified in the H01M 008/00 H01M 008/24 category, which is the category concerning fuel cell under the classification of the International Patent Classification. Effective exploitation of technology values is subject to the complementarities of organizational resources. The present study used the emerging technology of Fuel Cells as an example to show that firms may commercialize the values of technology according to their organizational resources. By aligning firms' patenting strategies and the imparities between book values and market values this study concludes a technological ambidexterity with respect to firms' technology development. The exploitative firms tend to file patents to defend their leadership in the product market as a result their technology is constrained within a firm's boundaries. The results show that patent renewing decisions are consequence of firm's constraints of complementary resources.

\section{Introduction}

Along the 20-year perspective legal entitlement duration, each patent would go through three renewal decision moments. Patent holder may check patent's status firstly, such as the citations, and then make the renewal decision. This decision becomes tougher nowadays for increasing holding numbers of patents and the maintenance cost particularly [1]. The United States Patent \& Trade Office (USPTO) data showed that from 1976 to 2009 there were one-third of patents abandoned before the 20 years of legitimate term arrived. USPTO, for example, sets the renewal fees at the three renewal points at $\$ 1,600, \$ 3,600$, and $\$ 7,400$, respectively. Danguy and de la Potterie [2] estimate the impact of renewal fees on patent maintenance rate and found that an increase of 1,000 Euros in renewal fees increased the abandoned rate by $12 \%$. It is a patent maintenance dilemma where on the one hand patent application is desirable for showing the performance of R\&D activities; on the other hand limited resource is for patent maintenance. The key is, will the patent's value be worth renewing? Thus assessment of patent value is essential. Unfortunately, patent's value is rarely observable with either patent transaction or technology licensing; for confidential reason, involved parties are often constrained disclosing details particularly the price and due diligences. To this end, patent citations are recognized as an indicative index which effectively reflects a firm's values of intangible assets [3-5].

Nevertheless, the citations regarding the fuel cell patents collected by the present study show a puzzling situation of patent holder's renewal decision-makings in which a handful of holders chose to renew their patents where there were no citations or only a small number. In other words, patent holders may renew patents in the light of other factors in addition to the value. This puzzling renewal behavior concurs 
with Bessen [6] where he showed that the patent citations explain little variance of the patent values. To resolve this puzzle, we propose a rationale by adopting the perspective of complementary resources of technology innovation [7, 8 ] to gain insights into firms' patent renewal decisions. We postulated that firm may choose to exploit the values of patents either with firm's own resources, such as the manufacturing and marketing channels, to launch products, or to gain immediate profits by licensing the technology to others that own those complementary resources. This complementary resource perspective may affect the patent renewal decisions in the above two cases as follows.

When firm owns the complementary resources, its goal is to produce products for customers; therefore technology as well as the patents is for the enhancement of protection in competitive competency. Citations, particularly the othercitations, may indicate the adoption of owned-technology by competitors, consequently deteriorating the competency in product market. In other words, patents that make no citations may actually benefit the firm by avoiding competition from others using similar technology. As a result we postulate that the firm with complementary resources would renew owned patents that make no or few citations.

Upon the second case where firm does not own complementary resources, to gain by selling products is less likely. Licensing therefore becomes an alternative widely adopted. Per technology licensee, being holdup by the technology sector is a critical problem that has to be resolved in advance [9]. To ease the holdup concern of licensee, patent that receives many other-citations could be indicative of the popularity and prospects of the technology in avoiding its obsolescence. As a result we postulate that the firm without complementary resources would renew patents if patents receive many citations. For the transaction of IPs (Intellectual Properties) such as patents, on the one hand as Arora and Ceccagnoli [7] pointed out that a potential licensee would naturally wish to verify the quality of the invention before paying for it. However, once the inventor discloses the invention, the potential licensee would have little incentive to pay for it. On the other hand, licensee may be afraid of being holdup with licensor's IPs. Patent's value is rarely observable with either patent transaction or technology licensing; for confidential reason, involved parties are often constrained disclosing details particularly the price and due diligences. Patent citations are recognized as an indicative index which effectively reflects a firm's values of intangible assets $[3,5]$. However, the patent citations regarding the fuel cell technology collected by the present study show that a handful of patent holders choose to renew their patents where there are no citations or only a small number.

Our study proposes a rationale by adopting the perspective of complementary resources of technology innovation $[7,8]$ to gain insights of firms' patent renewal decisions. The present study postulates that firms may seek to avoid the moral hazards by adopting the exploratory or exploitative strategies which are the consequences of firms' complementary resources. And the imparity (gap) of firm's book and market values serves the revelation of those intentions. Firms of wider imparity hinge on exploratory strategy that seeks wider acceptance of technology developed by other firms, whereas firms of smaller imparity hinge on exploitative strategy that aims to sell products rather than the technology. A key antecedence for the imparity is the complementary assets for products production and marketing. The finding implies that firms could reveal their intentions (exploitation or exploration) by widening or narrowing the market-tobook value imparity and consequently reducing the likelihood of the double moral hazards.

To verify our hypotheses, survival analysis was performed on patent data of the fuel cell technology and the result reveals a positive nonlinear impact of firms' market-tobook value ratio on patent's legal entitlement durations. As firm's market-to-book value ratio increases, patent's legal entitlement duration increases firstly and downturns as the market-to-book value ratio further increases.

\section{Literature Review}

Compared to other information, patents are often considered to be a superior source for the timely recognition of technological changes [10]. This may be attributed to the legal protection mechanisms that patents can induce for firm's R\&D investment, which means patents can effectively block rivals from competition [11]. Since not all of the technology inventors own sufficient resources to convert developed technologies into products for end consumption spot, market for technology transaction as a result burgeoned in the last decades. Nevertheless, the uncertainty related to technology transaction, particularly the double moral hazard problem stated above, shadows the market. In the following we will review the literature about patent valuation and move onto firm's ambidextrous strategies in realizing benefits.

2.1. Patent Valuation and Citations. Research concerning a firm's R\&D activities influencing market value has been abundant in the past two decades, where mostly motivated by the eminent work of Griliches [12], in which adopted Tobin's $\mathrm{Q}$ to measure firms' market value with respect to patent number and R\&D expenditure. Connolly and Hirschey [13] adopt Thomadakis' [14] approach to show the positive impact of a patent on firm value, where Thomadakis calls his approach the "relative excess valuation (EV)" defined as.

Trajtenberg [5] also echoes this finding that a patent's value positively correlates with the citation number of patents. Besides, Jaffe et al.s [15] survey shows that cited patents are more valuable than patents without any citation. In addition to value, patent citation considerations have also motivated further research into citation behavior, such as Carpenter et al. [3], who found that patents listed in RI100 attracted twice the citations of other patents outside the list; Trajtenberg [16] shows that there is a huge imparity between the US and Israel by comparing patent qualities in terms of citations. Breitzman et al. [17] indicate that the patent citation count is superior to the patent count for validating a patent's quality and a firm's technological competitiveness [18].

Klemperer [19] and Gilbert and Shapiro [20], for instance, introduced patent-breadth to instrument patent 
TABLE 1: Renewal and citation records of the fuel cell technology patents.

\begin{tabular}{|c|c|c|c|c|c|c|c|c|}
\hline \multirow{2}{*}{ Renewal } & \multicolumn{8}{|c|}{ Citations } \\
\hline & 0 & 1 & 2 & 3 & 4 & 5-10 & 11-15 & $>15$ \\
\hline 0 & 128 & 21 & 7 & 3 & 3 & 21 & 10 & 8 \\
\hline 1 & 49 & 40 & 21 & 21 & 19 & 42 & 16 & 18 \\
\hline 2 & 2 & 4 & 4 & 10 & 7 & 24 & 6 & 32 \\
\hline 3 & 3 & 4 & 8 & 13 & 4 & 28 & 16 & 21 \\
\hline
\end{tabular}

value. Greene and Scotchmer [21] construct a model to examine the impact factors of technical nonobviousness (inventive activity) and patent value disclosure. Gallini [22] suggests that the difficulty of "inventing around" a patent is of importance in determining its value. Not surprisingly, the evident positive correlation between patent counts and firm's market value renders a legitimate call for firm to engage in R\&D activities. From 1982 to 2002, the patent volume of the United States Patent \& Trade Office (USPTO) increased almost triple from 63,381 to 184,530 .

Nevertheless, the huge quality variations among patents call for better instrument to disentangle [23]. To avoid infringement of intelligent rights, patent citations are required to be stated clearly upon patent application, which is also a crucial reference grant the application boundaries of patents. In light of this rigorous process, Hall et al. [23] conjured that patent citations contain information regarding market evaluation on technology innovations and thus may be helpful for weighting the imparities of quality among patents. By comparing the patent qualities between the US and Israel, Trajtenberg [16] showed that there is a huge imparity between the two and patent value or technology leadership is positively correlated with citations. Jaffe et al. [15] survey also confirmed the finding that cited patents are more valuable than patents without any citation. In addition, Yang and Chen [24] concluded with electronics industry cases that weighting patents with the number of citations is a superior proxy for firm's market value. This patent citation approach receives tremendous attention and is furthermore refined with backward citations (being cited) [25] and forward citation (citing others) [5].

Thomas [26] indicated that while $90 \%$ of cited patents with more than 50 citations are renewed, $60 \%$ of uncited patents were renewed as well. This means that certain strategic values specific to patent holders are not fully reflected by the market evaluation. Besides, our data about the fuel cell technology shows the same puzzle in Table 1 . Table 1 reports the counts of patents with respect to their renewal and citation counts. The rows show the renewal counts and the columns depict the citations. According to Table 1, the records in the first column indicated that, in our sample, 128 patents are not renewed and have not received any citations either. And there are 54 patents were renewed only 1 3 times received no citations respectively. More than half of the patents were renewed with citations less than 5 .

This puzzle motivates the present work to explore the determinants for patent renewal decisions. Maurseth [27] found that the patents receiving high citations from across technology field survive longer whereas the patents receiving high citations from the same field lapse earlier. Typical firm of the type would be Valence Technology which is a battery company in the US that specializes in lithium-ion polymer but owns several important patents in fuel cell technology. Typical firm of the type would be Motorola that is a wellknown enterprise worldwide for its communication products (although its handset unit was divested to Google later on) and the battery is one of the major development application on fuel cell technology.

2.2. Antecedents of Exploration and Exploitation. The objectives of technology innovation are often multifold. For example, it may help to gain protection from imitation in light of laws, acquire necessary complementary resources, enhance capabilities in imitating rivals' technologies, or pursue the leadership on the technological edges. To these ends, certain patenting strategies are important and necessary; for example, one can gain market exclusivity to deter followers (or rivals) by patenting critical technologies or use patents to gain revenues via licensing as others step into the boundaries set up by other patents or use patents as $R \& D$ performance measures to motivate R\&D personnel [4].

To simplify understanding, we will begin with a novice condition where the market is composed of firms equipped either with or without complementary assets, such as marketing resources. For those equipped with complementary assets, they may take invented technologies as input production factors and share the goal of selling their final products, product oriented firms. On the other hand, those which do not have complementary assets have no choice but to sell or license their invented technologies to generate profit, technology oriented firms. For product-oriented firms, due to their revenues being gained by selling end products, it is essential for them to deter any harmful imitations by their rivals. Patents are one of the most powerful instruments to achieve this end. Meanwhile, it is critical for leading firms to innovate as fast as possible to shake out their followers' bypass inventions. As a result, those leading firms with powerful patented technologies may take two patenting actions. Firstly, they use patents as one of the weapons to deter followers. When they choose a technology for patenting, its goal is to defend their territory; therefore, knowledge-spillover benefiting followers due to the declaration of patent applications is strongly prohibited. Secondly, to speed up innovation it may be helpful to have knowledge diffused within an organization. Building new technology on those existing and owned technologies may help not only utilize those existing 
technologies but also strengthen technology leadership. In light of these two patenting actions, the first action is likely to cause a low score for other-cited citations and a high score for self-citing citations due to the second action. This is why we call the firms with these two characteristics "exploiters."

For technology oriented firms, they generate revenue by selling or licensing. Therefore, it is critical to have technologies that are widely recognized by industrial users; that is, firms that do not have critical technologies to compete with the leading players. To this end, technology oriented firms can choose to invent and patent technologies for the reason of solely selling or licensing them. These types of firms act as an explorer for those firms that choose not to develop the technologies by themselves.

From a strategic perspective, firms make choices in line with resources at hand. That is to say, firms may choose to match their patenting strategies with their own resources to optimize investment returns. In the present study, we hypothesize that a product oriented firm would choose to employ the "exploiter" style patenting strategy to match its resources in manufacturing and marketing whereas the technology oriented one would take the "explorer" style patenting strategy to compromise the lack of resources in manufacturing and marketing in order to achieve competitiveness with strong R\&D capabilities.

\section{Methods-Survival Analysis}

The studied patents are collected from a database provided by the US Patent and Trademark Office. As online searching was made available after 1976, the present study took 1976 as the initial year to conduct the patent search. Up to 2001, there are 2269 patents classified in the H01M 008/00 H01M $008 / 24$ category, which is the category concerning fuel cell technologies under the classification of the international patent classification (IPC). Since the market-to-book ratio is only available for public firms and can be acquired from the Compustat database, the 2269 data set is reduced to 1090 patents owned by 93 companies. Excluding those companies holding patents without any citations, the data set is furthermore reduced to 70 companies for analysis.

Survival analysis is a method widely used in medical researches such as the effects of treatment resulting in the length of patents' life spell. This method is also adopted by numerous social studies to investigate social problems such as the length of striking and the length of unemployment. Quite often it is given another name as "duration analysis" to reflect its usage.

A typical duration analysis would begin with a definition about the time horizon of the studied topic, including the time of origin (noted $t_{0}$ ) and the spot of the change (noted $\left.t_{1}\right)$. For the present study, $t_{0}$ is set at the moment when patent is granted and $t_{1}$ is the moment when patent holder chooses not to renew the patent. For some cases, observations are terminated due to reasons such as the end of study instead of intended renewal decision. This kind of cases is treated as censored observations which are pervasive and usually unavoidable cases in the duration analysis.
For duration analysis, the duration function is defined as follows. Let $f(t)$ be a continuous probability density of a random available $T$, where $t$ a realization of $T$ is the representation of the duration. The corresponding cumulative distribution is given by $F(t)=\int_{0}^{t} f(s) d s=\operatorname{Pr}(T \leq t)$. Then the probability that the spell is of length of $t$ can be expressed by $S(t)=1-F(t)=\operatorname{Pr}(T \geq t)$, which is the survivor function. Given that the life spell has lasted until $t$, the probability that it will be terminated at the next instant time change $(\Delta)$ can be defined as $\operatorname{Prob}(t \leq T \leq t+\Delta \mid T \geq t)$ which can be characterized by a hazard function:

$$
\begin{aligned}
h(t) & =\lim _{\Delta t \rightarrow 0} \frac{\operatorname{Pr}(t \leq T \leq t+\Delta t \mid T \geq t)}{\Delta t} \\
& =\lim _{\Delta t \rightarrow 0} \frac{F(t+\Delta t)-F(t)}{\Delta t S(t)}=\frac{f(t)}{S(t)} .
\end{aligned}
$$

The hazard function specifies the instantaneous rate of completion of a spell at $T=t$, conditional upon survival to time $t$.

Two frequently used assumptions to adjust the effects of covariates on the survival are accelerated failure-time (AFT) model and multiplicative or proportional hazard (PH) model. In the accelerated failure-time model, the natural logarithm of the survival time $\ln (t)$ is a linear function of the covariates, yielding a linear equation: $\ln t_{j}=X_{j} \beta+Z_{j}$, where $X_{j}$ is a vector of covariates, $\beta$ is a vector of regression coefficients, and $Z_{j}$ is the error with density $f(t)$. The distribution of the error term determines the regression model. If $f(t)$ is a normal density function, the lognormal regression model can be obtained. Similarly, if $f(t)$ is a logistic density, the log-logistic regression model is obtained. If $f(t)$ is extremevalue density, then the exponential and the Weibull regression models result (STATA, release 8).

In this paper, we adopted the commonly used proportional hazard rate model (known as Cox PH model), in which the explanatory variables, or covariates, have a multiplicative effect on the hazard function. The basic proportional hazards regression assumes the relationship: $h(t)=h_{0}(t) \exp \left(\beta_{1} x_{1}+\right.$ $\left.\beta_{2} x_{2}+\cdots+\beta_{k} x_{k}\right)$, where $h_{0}(t)$ is the baseline hazard function (STATA, release 8).

The analysis will focus on estimating the survival function $S(t)$ and the hazard function $h(t)$, using nonparametric as well as parametric methods to fit the regression equations. Parametric methods assume that survival spell follows particular distributions, such as Weibull, lognormal, and loglogistic distributions.

The dependent variable of the models is the length of legal entitlement for patent. This entitlement requires periodic renewal and along the 20 years lifespan three renewal points are set by the USPTO. Figure 1 shows the coding for the variable. Basically, each patent is assumed of 20 years of legal entitlement. That is to say, it survives only 20 years at most. A typical 20-year lifespan is divided into four periods as indicated in Figure 1: before the fourth year, from the fourth year to the eighth year, from the eighth year to the twelfth year, and after the twelfth year. Consequently, the three renewal decision points are around the 3.5th, 7.5th, and 11.5th year. For 


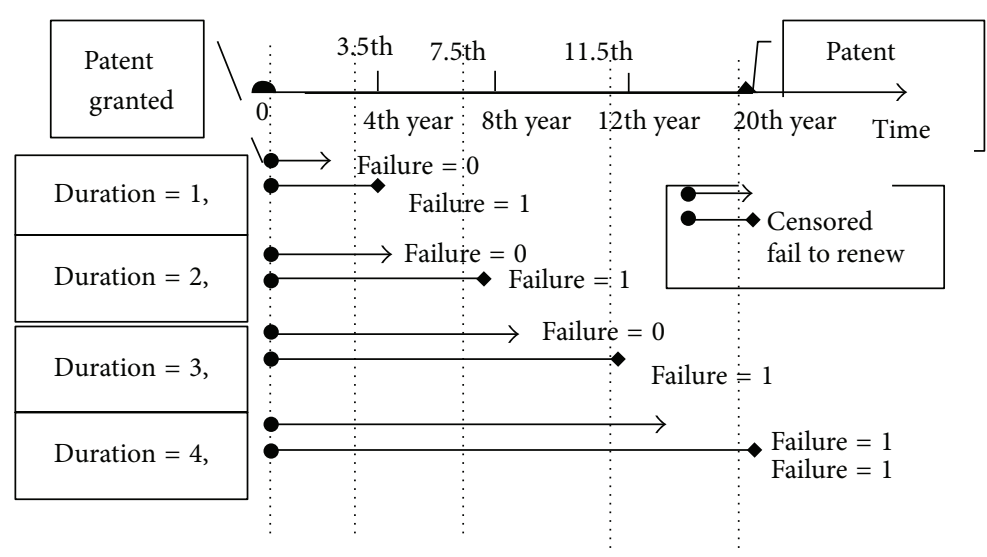

Figure 1: Patent classifications in the survival regression.

the present analysis, duration is coded " 1 " if it is not renewed; coded " 2 " if it is renewed only once; coded " 3 " if it is renewed twice; coded " 4 " if it is renewed thrice. Since duration analysis allows censored data, this censorship is included with coding of the "failure" option. The "failure" option is coded " 0 " if the patent is observed within the 20-year lifespan, otherwise coded "1." Observations are sorted according to the averaged MTB ratio from 2000 to 2002 . The top $25 \%$ percent of the observations are classified as persuader type firms and coded "1" for the dummy variable "persuader." The bottom 25\% percent firms are assigned as the defender type firms and coded "1" for the dummy variable "defender." Other firms are coded " 0 " for both dummy variables.

To verify our hypotheses, analysis of variance (ANOVA) was performed with the following independent variables.

(i) Self-Citing. When applying for a patent, applicant has to state clearly the existing technologies and the literature which the invention is based on. Self-citing depicts those cited patents that are owned by the same patent assignee; for the present case, it is the company that owns the patents.

(ii) Other-Citing. This variable is similar to self-citing but with patents that are not owned by the same assignee.

(iii) Self-Cited. The USPTO database provides information about citations made by other following patents once the patents are granted. A self-cited citation recodes the number of accumulated citations of a firm's patents, cited in the following patents that are also owned by the same firms.

(iv) Other-Cited. This variable is similar to the self-cited variable which recodes the accumulated cited citations that are made by other patent owners.

The dependent variable for ANOVA modeling is " marketto-book value ratio." Market-to-book value is a ratio widely adopted in financial analyses $[28,29]$ for explaining business financial behavior. It is also attempted for the valuation of a firm's intelligent assets [28-32]. Book value is the number calculated with the traditional accounting system, that is, the balance sheet which records the tangible assets such as machines and land. Hence, when the tangible assets are deducted from the market value, the rest might most likely reflect the value for the intangible assets. For comparison across firms, the following ratio with normalization is adopted in the present study:

$$
\text { Market-to-book ratio }=\left|\frac{\text { market value }- \text { book value }}{\text { book value }}\right| \text {. }
$$

\section{Analysis and Results}

4.1. Descriptive Statistics. The patent data were collected by a group of experts in fuel cell technology from United States Patent and Trademark Office (USPTO) and the search engine, Knowledgist, was used for the identification of fuel cell technology related patents. Our data range is for the patents between 1976 and 2001 that were granted in the US. According to the IPC definition on fuel cell technology, there were 2269 patents during this period. By matching with the Compustat database, of the 2269 patents, 1090 patents belong to 93 public companies in the US. By excluding companies that do not have any citations, 70 companies were used for further analysis. The mean citations for self-citing is $0.62,9.88$ for other-citing, 0.58 for self-cited, and 6.00 for other-cited. The mean value for the market-to-book ratio is 2.04 .

4.2. ANOVA: Self-Citing versus Other-Cited. To verify our hypotheses regarding the patenting strategy fit (exploiter versus explorer) argument, we perform an analysis of variance on self-citing and other-cited factors. The results are shown in Table 2.

The modeling in Table 2 attains significance at a $1 \%$ level $\left(F=4.16, P=0.0092, R^{2}=0.1590\right)$. The "self-citing" main effect is not significant $(F=0.43, P=0.5137)$; however the "other-cited" main effect is significant at a $5 \%$ level $(F=6.64, P=0.0122)$. The interactive effect of the two variables, which is the primary concern of the present study, is significant at a $10 \%$ level $(F=3.18, P=0.0791)$. A $t$-test on the two cells (explorer versus exploiter) of the interaction effect is conducted and the derived $t$-value is 1.50 $(P$ value $=0.08)$. The mean value of the market-to-book ratio 
TABLE 2: Analysis of the variance results for the market-to-book-ratio on self-citing and other-cited citations.

\begin{tabular}{lccccc}
\hline Source & Partial SS & Df & MS & $F$ & Prob $>F$ \\
\hline Model & 111.55 & 3 & 37.18 & 4.16 & $0.0092^{* * *}$ \\
Self-citing & 3.85 & 1 & 3.85 & 0.43 & 0.6437 \\
Other-cited & 59.38 & 1 & 59.38 & 3.18 & $0.0122^{* *}$ \\
Interaction & 28.44 & 1 & 28.44 & $0.0791^{*}$ \\
Residual & 590.02 & 66 & 8.94 & \\
\hline Total & 701.57 & 69 & 10.17 & \\
\hline
\end{tabular}

Note: * represents $P<0.1, * *$ represents $P<0.05$, and $* * *$ represents $P<0.01$.

TABLE 3: The statistical means for the market-to-book-ratio with respect to the four situations composed of the two self-citing and other-cited citations.

\begin{tabular}{lccc}
\hline & & \multicolumn{2}{c}{ Other-cited } \\
& & High & Low \\
\hline \multirow{2}{*}{ Self-citing } & High & 1.67 & 1.27 (exploiter) \\
& Low & 2.78 (explorer) & 1.68 \\
\hline
\end{tabular}

for the explorer patenting style is 2.78 (standard deviation of 1.03 ) and 1.27 (standard deviation of 0.36 ) for the exploiter patenting style. Table 3 shows the statistical means for the four situations composed of the two self-citing and othercited citations at both high and low levels, respectively.

4.3. Cases of Exploiter Style Patenting Strategy. Motorola is a well-known enterprise in the US that specializes partially in communication products such as mobile handsets. For fuel cell technology, Motorola is one of the leading companies specializing in portable fuel cells for mobile usage. It particularly focuses on direct methanol fuel cells that can be employed as a power source for mobile phone handsets, PDA, and such products. Motorola's fuel cell related patents attain an average self-citing citation rate of 0.64 per patent (higher than the sample mean of 0.62 ) and an average other-cited citation rate of 2.86 per patent (lower than the sample mean of 6.00). Its market-to-book ratio is 1.47 (lower than the sample mean of 2.04). It is a typical exploiter style firm.

Daimler Chrysler (DC) is a well-known German company that gained its brand equity largely in luxury automobiles. It produces more than four million automobiles yearly. Concerning fuel cell technology, DC is famous for its Proton-Exchange Membrane technologies. It helps DC to maintain a leading position in powering automobiles with fuel cell engines. Back in 1994, DC made the first prototype fuel cell car. Today, the technology has been applied to public transportation for a test run. DC is also allied with UPS, providing delivery vehicles for a test run in the city of Hamburg. The fuel cell patents owned by DC attain an average self-citing citation rate of 0.75 per patent ( $>$ sample mean 0.62 ) and an average other-cited citation rate of 4.42 (< sample mean 6.00). Its market-to-book ratio is 0.38 (< sample mean 2.04). It is another example of an exploiter style company.
4.4. Explorer Style Patenting Strategy Cases. Valence Technology (VT) is a US battery company operating. The company specializes in lithium-ion polymer that is essential for materials used in rechargeable batteries. VT owns several important fuel cell technology patents. VT is also a research partner in the area of backup powers for military uses for the US government. VT attains an average self-citing citation of 0.5 (< sample mean of 0.62 ) and other-cited citation of 11.5 (> sample means of 6.00). The average market-to-book ratio is 9.76 (> sample mean of 2.04). VT is a typical model of a company using explorer style patenting.

Another case is Imperial Chemical, which attains an average self-citing of 0 (< sample mean of 0.62 ) and other-cited of 8 (> sample mean of 6.00). Its average market-to-book ratio is 10.66 (> sample mean of 2.04). Texas Instruments also attains an average self-citing of $0(<$ sample mean of 0.62$)$ and othercited of 7 ( $>$ sample mean of 6.00). Its average market-to-book ratio is 3.09 (> sample mean of 2.04). This is a typical example of an explorer style patenting company.

In addition to the product market which usually processes arm's length transactions, there exists a market for technology transactions in which buyer's value and seller's cost are initially uncertain [33]. This technology market may not be operated as efficiently as the product market since asymmetric information could end with serious holdup problems between the two parties. By distinguishing the patent holders into explorers (technology-oriented) and exploiters (product-oriented), the renewal data analyses show a significant effect where firms are maintaining their patents in the light of accrued citations and the complementary resources that the holders owned. The anomaly that patents are renewed without or with few citations is consequently resolved by this differentiation. Since the MTB indicator (in distinguishing explorers from exploiters) is available for firms via public information sources, using it to evaluate the patent value to buyer as well as seller could significantly ameliorate asymmetric information in between and, as a result, improve the market efficiency of technology transactions.

Johnstone et al. [34] criticized that the existing patent analysis is short for the link between patents and the release of successful products. An obvious reason is attributed to the need of a bundle of patents to design and produce products. Nevertheless, a subtle and less addressed hindrance may be attributed to the ineffective market for transacting need patents among technology developers and business parties. A successful product would not be released unless the needed 
set of technologies is systemized. Our study shows that the enhancement of technology transactions may benefit from the recognition of firm's characteristics in developing technology.

\section{Conclusion}

This paper adopts survival analysis to investigate firm's decision-making on patent renewal. By holding the patent related information as control variables, the survival regression results show that patent renewal decisions are subject to firm's complementary resources. The result confirms our theory that technology-oriented firms (explorers) are less likely to renew patents than the product-oriented firms (exploiters). Therefore, it resolves the puzzle of why patents are renewed even without any citations. The study furthermore identifies a nonlinear relationship in inverse $\mathrm{U}$ shape between the MTB ratio and the patent legal entitlement duration.

Previous works show that patent citations are useful instrument to estimate a patent's value. In light of those ongoing works, the relationship between a firm's R\&D performance (e.g., the count of patents) and economic value is explored. As production factors switch from tangible labor, land, and capital inputs to intangible technology and knowledge inputs, the latter have taken a large share of firms' strategic attention. To compete in this new battle, firms not only need to focus on the accumulation of strategic assets but also utilize those assets optimally. Amit and Schoemaker [35] show that firms adopt R\&D strategies to achieve favorable patent portfolios due to the uniqueness of the resources they own. This patent portfolio helps to reduce the costs and time consumption to achieve valuable innovation. In other words, the cause and effect relationship between a firm's value and intangible assets (e.g., patents) is almost indisputable. Nevertheless, this understanding is far from appreciation in the evaluation of the contribution of intangible assets to a firm's value. The present study aims to provide a strategic perspective on how firms in the fuel cell industry implement patenting strategies in light of their complementary resources.

Our empirical results show that fuel cell firms can exploit the value of their R\&D activities through two different strategies: exploitation or exploration. Exploitative firms choose to deter their rivals by limiting knowledge diffusion across firms for imitation. To this end, exploitative firms may cast heavy fixed investment on tangible assets, such as land and machines, to utilize the developed techniques and produce end products to reach customers. Our samples of fuel cell firms in exploitative strategy indicate a mechanism for attaining this goal via a patent consolidation of technology portfolio with characteristics of high number of self-citing citations and low number of other-cited citations.

Exploratory firms on the other hand seek to generate profit by technology licensing. In this case, it is essential to develop technologies that have been adopted by relevant (particularly downstream) firms. In the long run, knowledgespillover may be beneficial for a firm by gaining the dominant position in supplying the required technologies.
Consequently, these firms may try to profit by distributing developed technologies with a role of technology "exploration," a mechanism for attaining the goal by carrying patenting characteristics of high external citations and low self-citing ones. In the light of the two (exploitation versus exploration) orientations, our samples show that the gap between market value and book value is significantly wider for exploratory firms than it is for the exploitative ones.

It is not uncommon for wide imparities between a firm's book value and market value to exist. This is even more widely observed in the knowledge-based and technology intensive industries. A common explanation about this imparity is that the book value merely reflects the tangible assets owned by a firm, such as plants and equipment, whereas the market value includes not only those tangible assets but also intangible assets such as a firm's brand, technologies, and management capabilities [36-38].

Earlier studies have shown that the accumulation of patents does affect firms' value. However, when holding constant of patent number, firms' value still varies at a wide difference. This hints at the existence of other affects besides patent counts. Thus, citations per patent are considered as weights for each patent. Nevertheless, patent owners who also play a critical role in exploiting the potentials of patents attract minimal attention. The present study shows that patenting strategies abided by firms' complementary assets do induce different valuation concerns by both market and shareholders.

For firms that hold complementary assets, such as marketing capabilities, may take a product orientation approach to generate profits by selling end products directly to buyers. The firms may strengthen their leadership in the product market by building a technology "exploiter." The exploiter is constructed with a number of patents developed and linked to each other. These patents carry two characteristics in low other-citied and high self-citing citations. For firms that lack complementary assets, they are likely to be limited in their ability to generate profits by selling or licensing technologies. As a result, their R\&D resources may be spent on building leadership in technologies, which would attract the attention of firms which are short of competitive technologies to compete in the relevant product market. In other words, they act as technology "explorers" for downstream firms. An explorer may consider developing technologies rendered in patents with two characters in citations of high othercited and low self-citing. The two patenting strategies affect a firm's market-to-book ratio by stretching to the two extremes. On one hand, the exploiter patenting style reduces the gap between the market value and the book value; hence, the market-to-book ratio moves toward the minimum due to tangible assets dominating the ratio. On the other hand, the explorer patenting style enlarges the gap; hence, it makes the ratio move toward the maximum such that the intangible assets become the dominator.

This finding provides the following managerial implications for R\&D management. For firms that do not hold complementary assets to sell their end products to buyers it is essential for them to build technologies that attract downstream users. The present study shows that to attract downstream users they need to develop technologies that 
result in patents with two citations characteristics, low selfciting and high other-cited. Low self-citing indicates that the technology is relatively independent of earlier technologies, which can reduce buyers' concern about piracy accusations and technology holdup. The technology buyer concern upgrading issue, especially high other-cited indicates that the technology may have been widely adopted by the industry.

In addition, this study provides an alternative perspective about exploiting the information contained in patent citations (an extension of Lin and Chen's [18] framework). By dividing citation information into four dimensions, selfciting, other-citing, self-cited, and other-cited, a refined strategic fit could be achieved in light of firms' $R \& D$ approaches and their complementary assets resources. One issue lacking in this study is how a strategic fit could affect firm performance? This question is difficult to answer for two reasons. Firstly, most fuel cell related products are not commercialized yet. The estimation of profits solely on fuel cell technology is subject to a large variation. Secondly, the economic contribution attributed to fuel cell technology within a firm is unclear. This is especially true for conglomerates, such as Motorola, 3M, and Dupont, all of which produce thousands of products.

There are limits of the study like, first of all, the data limit. By modeling the patent durations to examine the determinants of patent renewal, in addition to the patent information, the firm specific indicator (MTB) was the main variable used for our hypothesis testing. Nevertheless, this indicator is incomplete for some of the private firms and therefore was dropped from the analyses. This may draw a concern for the firms operated privately. Second, though we explain patent duration using the firm characteristics (MTB), other firm level variables may be worth being included in future study such as marketing power to better represent firm's complementary resources. Finally, the fuel cell industry may not be representative of other industries which may limit the generalizability of the findings in the present study.

Despite the limits, the study reveals some interesting results that contribute to the literature. First, few studies in the patent literature discuss patent maintenance decisions which are worthy of notice in the light of costly patent renewal fee nowadays. de Rassenfosse and van Pottelsberghe de la Potterie [39] also call for an optimal fee policy via renewal fee structure from the policy making perspective. The results of the present study imply that excluding factors of firm characteristics may hinder the approach of the "optimality" in fee setting. The information related to patents (such as the citations) is limited in the revelation of patent value to firms and certainly cannot justify thoroughly the motives in patent renewal.

Second, since researchers regarded patent citations as an important indicator in evaluating patent value, we provide a novel method to reveal patent value and patent renewal behavior by using the firm characteristic variables, which plot a new scenario in describing firm's consideration in patent maintenance. This novel method opens a gateway to link another huge literature regarding asset specificity of the transaction-costs economics [40]. This linkage may endeavor the adoption of transaction-costs perspectives to deepen our understanding of firm's patenting strategy.

\section{Conflict of Interests}

The authors declare that there is no conflict of interests regarding the publication of this paper.

\section{References}

[1] X. Jin, S. Spangler, Y. Chen et al., "Patent maintenance recommendation with patent information network model," in Proceedings of the IEEE 11th International Conference on Data Mining (ICDM '11), pp. 280-289, IEEE, Vancouver, Canda, December 2011.

[2] J. Danguy and B. V. P. de la Potterie, "Cost-benefit analysis of the community patent," Journal of Benefit-Cost Analysis, vol. 2, no. 2, pp. 1-43, 2011.

[3] B. Carpenter, J. L. Hart, and J. P. Miller, "Jump starting the patent search process by using subject-oriented databases," Database, vol. 21, no. 6, pp. 20-23, 1998.

[4] B. H. Hall, A. Jaffe, and M. Trajtenberg, "Market value and patent citations," The RAND Journal of Economics, vol. 36, no. 1, pp. 16-38, 2005.

[5] M. Trajtenberg, "A penny for your quotes: Patent citations and the value of innovations," The RAND Journal of Economics, vol. 21, no. 1, pp. 172-187, 1990.

[6] J. Bessen, "The value of U.S. patents by owner and patent characteristics," Research Policy, vol. 37, no. 5, pp. 932-945, 2008.

[7] A. Arora and M. Ceccagnoli, "Patent protection, complementary assets, and firms' incentives for technology licensing," Management Science, vol. 52, no. 2, pp. 293-308, 2006.

[8] D. J. Teece, "Capturing value from knowledge assets: the new economy, markets for know-how, and intangible assets," California Management Review, no. 3, pp. 55-79, 1998.

[9] J. Bessen, "Holdup and licensing of cumulative innovations with private information," Economics Letters, vol. 82, no. 3, pp. 321326, 2004.

[10] H. Ernst, "Patent information for strategic technology management," World Patent Information, vol. 25, no. 3, pp. 233-242, 2003.

[11] W. M. Cohen, R. R. Nelson, and J. P. Walsh, "Protecting their intellectual assets: appropriability conditions and why U.S. manufacturing firms patent (or not)," NBER Working Paper no. 7552, The National Bureau of Economic Research, 2000.

[12] Z. Griliches, "Market value, R\&D, and patents," Economics Letters, vol. 7, no. 2, pp. 183-187, 1981.

[13] R. A. Connolly and M. Hirschey, "Market value and patents: a bayesian approach," Economics Letters, vol. 27, no. 1, pp. 83-87, 1988.

[14] S. B. Thomadakis, "A value-based test of profitability and market structure," Review of Economics \& Statistics, vol. 59, no. 2, pp. 179-185, 1977.

[15] A. B. Jaffe, M. Trajtenberg, and M. S. Fogarty, "Knowledge spillovers and patent citations: evidence from a survey of inventors," The American Economic Review, vol. 90, no. 2, pp. 215-218, 2000.

[16] M. Trajtenberg, "Innovation in Israel 1968-1997: a comparative analysis using patent data," Research Policy, vol. 30, no. 3, pp. 363-389, 2001. 
[17] A. Breitzman, P. Thomas, and M. Cheney, “Technological powerhouse or diluted competence: techniques for assessing mergers via patent analysis," $R$ \& $D$ Management, vol. 32, no. 1, pp. 1-10, 2002.

[18] B.-W. Lin and J.-S. Chen, "Corporate technology portfolios and R\&D performance measures: a study of technology intensive firms," R \& D Management, vol. 35, no. 2, pp. 157-170, 2005.

[19] P. Klemperer, "How broad should the scope of patent protection be?" RAND Journal of Economics, vol. 21, no. 1, p. 113, 1990.

[20] R. Gilbert and C. Shapiro, "Optimal patent length and breadth," The RAND Journal of Economics, vol. 21, no. 1, pp. 106-112, 1990.

[21] J. R. Green and S. Scotchmer, "On the division of profit in sequential innovation," RAND Journal of Economics, vol. 26, p. 20, 1995.

[22] N. T. Gallini, "Patent policy and costly imitation," RAND Journal of Economics, vol. 23, p. 52, 1992.

[23] B. H. Hall, A. B. Jaffe, and M. Trajtenberg, "Market value and patent citations: a first look," NBER Working Paper no. 7741, National Bureau of Economic Research, 2000.

[24] C.-H. Yang and J.-R. Chen, "Innovation and market value in newly-industrialized countries: the case of Taiwanese electronics firms," Asian Economic Journal, vol. 17, no. 2, pp. 205-220, 2003.

[25] M. P. Carpenter, M. Cooper, and F. Narin, "Linkage between basic research literature and patents," Research Management, vol. 23, no. 2, pp. 30-35, 1980.

[26] P. Thomas, "The effect of technological impact upon patent renewal decisions," Technology Analysis \& Strategic Management, vol. 11, no. 2, pp. 181-197, 1999.

[27] P. B. Maurseth, "Lovely but dangerous: the impact of patent citations on patent renewal," Economics of Innovation and New Technology, vol. 14, no. 5, pp. 351-374, 2005.

[28] E. F. Fama and K. French, "Size and book-to-market factors in earnings and returns," The Journal of Finance, vol. 50, no. 1, pp. 131-155, 1995.

[29] E. F. Fama and K. R. French, "Average returns, B/M, and share issues," Journal of Finance, vol. 63, no. 6, pp. 2971-2995, 2008.

[30] G. Roos and J. Roos, "Measuring your company's intellectual performance," Long Range Planning, vol. 30, no. 3, pp. 413-426, 1997.

[31] T. A. Stewart, "Brain power," Fortune, vol. 135, no. 5, pp. 104-108, 1997.

[32] K.-E. Sveiby, "Intellectual capital thinking ahead," CPA Australia, vol. 68, no. 5, pp. 18-23, 1998.

[33] O. Hart, "Hold-up, asset ownership, and reference points," Quarterly Journal of Economics, vol. 124, no. 1, pp. 267-300, 2009.

[34] N. Johnstone, I. Haščič, and D. Popp, "Renewable energy policies and technological innovation: evidence based on patent counts," Environmental and Resource Economics, vol. 45, no. 1, pp. 133-155, 2010.

[35] R. Amit and P. J. H. Schoemaker, "Strategic assets and organizational rent," Strategic Management Journal, vol. 14, no. 1, pp. 33-46, 1993.

[36] M. E. Booth and G. Philip, "Technology, competencies, and competitiveness: the case for reconfigurable and flexible strategies," Journal of Business Research, vol. 41, no. 1, pp. 29-40, 1998.

[37] G. Hamel, "The end of progress," Business Strategy Review, vol. 11, no. 3, pp. 69-78, 2000.

[38] Johnson, "Making the most of technology," in Foodservice Equipment \& Supplies, vol. 52, Reed Business Information, 1999.
[39] G. de Rassenfosse and B. van Pottelsberghe de la Potterie, "The role of fees in patent systems: theory and evidence," Journal of Economic Surveys, vol. 27, no. 4, pp. 696-716, 2013.

[40] O. E. Williamson, The Economic Institutions of Capitalism, Free Press, New York, NY, USA, 1985. 

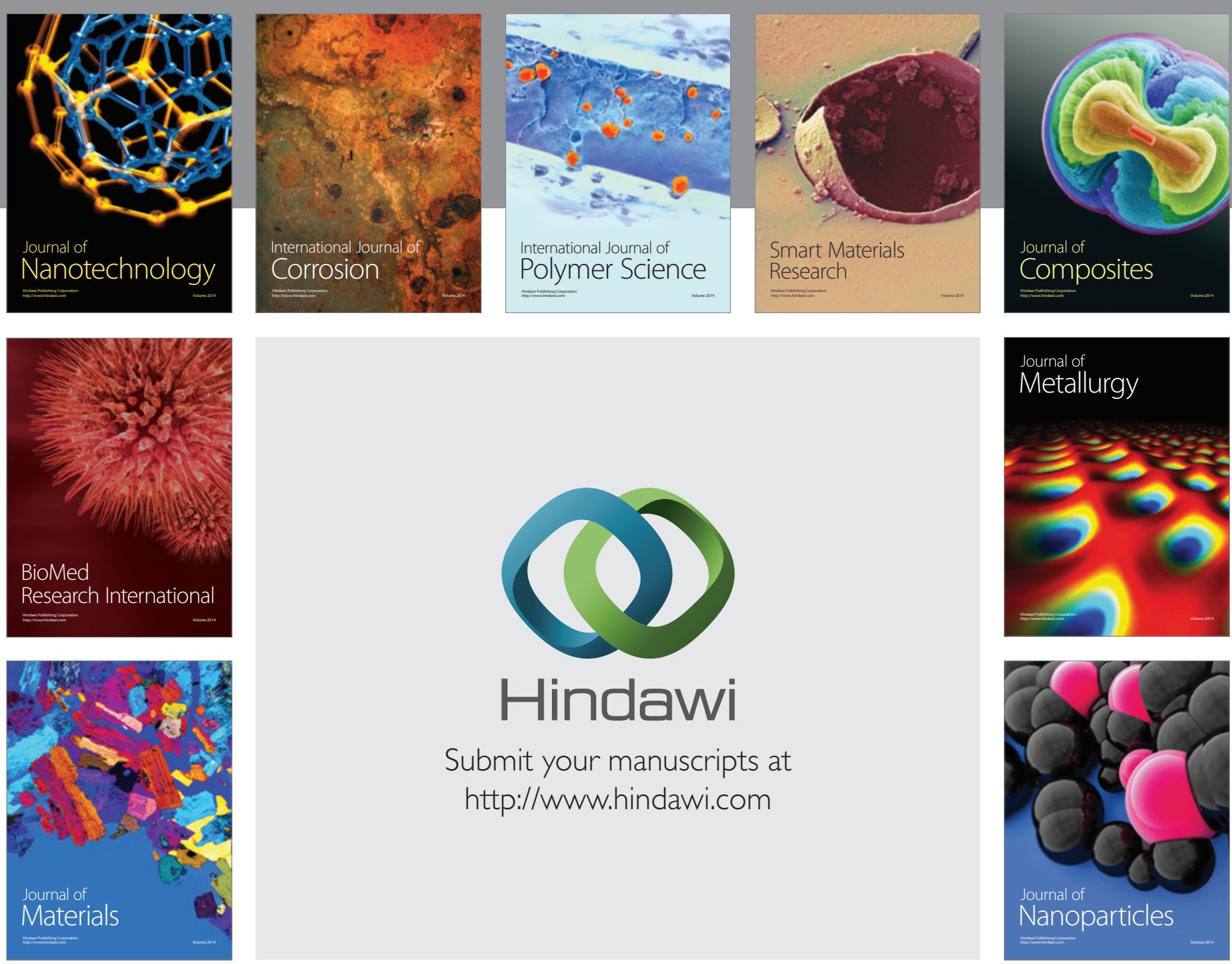

Submit your manuscripts at http://www.hindawi.com
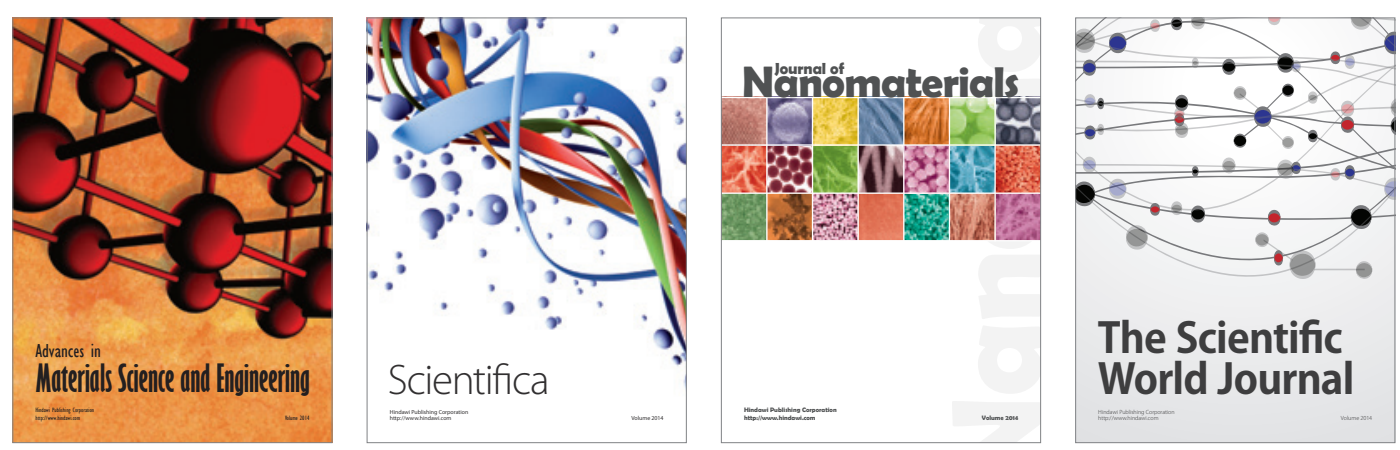

\section{The Scientific World Journal}
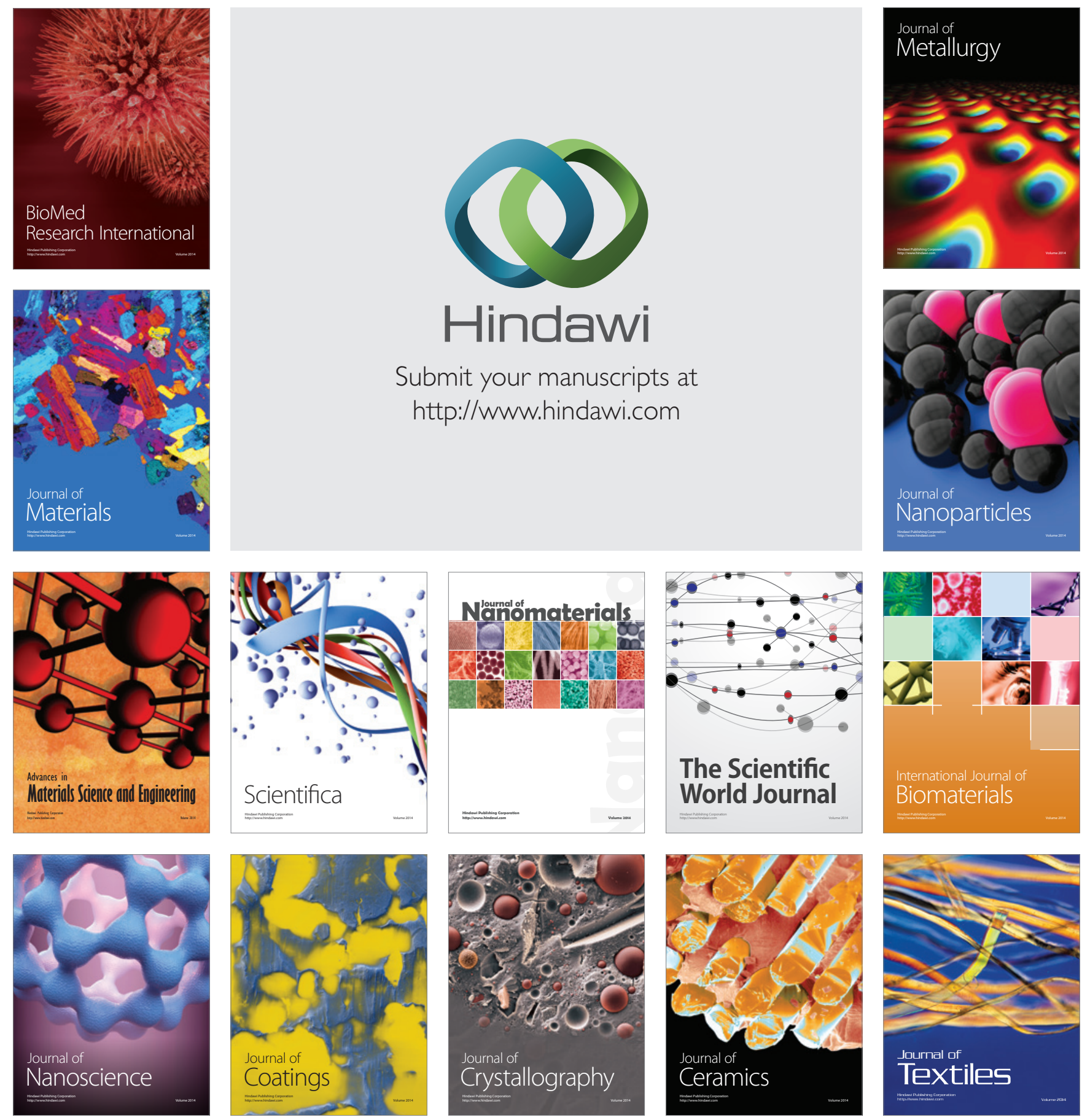